\title{
Peningkatan Kapasitas Aparatur Pemerintahan \\ Desa dan Masyarakat Melalui Pelatihan Administrasi Pemerintahan Di Desa Sukamenak Kecamatan Cikeusal Kabupaten Serang
}

\author{
Budi Hasanah ${ }^{1}$, Ahmad Sururi ${ }^{2}$ \\ ${ }^{1)}$ Prodi Administrasi Publik FISIP Universitas Serang Raya \\ ${ }^{2)}$ Prodi Administrasi Publik FISIP Universitas Serang Raya
}

\begin{abstract}
Abstraksi
Tujuan dari kegiatan pengabdian masyarakat ini adalah memberikan pelatihan administrasi pemerintahan desa dan tata kelola pelaporan keuangan desa dalam meningkatkan kapasitas aparatur pemerintahan desa. Diharapkan melalui kegiatan tersebut akan mendorong tata kelola pemerintahan desa yang akuntabel dan transparan serta melahirkan kader-kader desa yang memiliki pengetahuan, sikap dan keterampilan yang baik. Sedangkan Metode kegiatan yang digunakan adalah Participatory Learning And Action. Kegiatan ini dilakukan dengan menekankan pada kegiatan ceramah, diskusi, curah pendapat yang dilakukan secara interaktif dengan anggota kelompok dan dilanjutkan dengan aksi atau kegiatan riil yang relevan dengan materi pemberdayaan masyarakat. Hasil kegiatan pengabdian masyarakat berjalan sesuai dengan rencana yang telah ditetapkan, masyarakat memilki respon dan antusias terhadap pelatihan dan tercipta perubahan pengetahuan, sikap dan keterampilan.
\end{abstract}

Kata Kunci : Peningkatan Kapasitas Aparatur, pelatihan administrasi pemerintahan desa.

\begin{abstract}
The purpose of this community service activity is to provide training on village government administration and village financial reporting governance in improving the capacity of village government apparatus. It is hoped that through these activities it will promote accountable and transparent village governance and give birth to village cadres who have good knowledge, attitude and skills. While the activity method used is Participatory Learning And Action. This activity is conducted by emphasizing on lecture, discussion, brainstorming conducted interactively with group members and continued with action or real activity that relevant with material of society empowerment. The results of community service activities run in accordance with predetermined plans, the community has a response and enthusiasm for training and created changes in knowledge, attitudes and skills.
\end{abstract}

Keywords: Capacity Building Apparatus, village administration administration training. 


\section{A. Pendahuluan}

Desa sebagai struktur organisasi pemerintahan paling rendah menjadi garda terdepan pelayanan yang langsung bersentuhan dengan masyarakat, oleh sebab itu kemampuan dan kapasitas aparatur pemerintahan desa memegang peranan yang sangat penting. Dengan kompleksitas permasalahan yang dihadapinya, aparatur pemerintahan desa dituntut untuk memiliki perhatian dan tanggung jawab terhadap masyarakat desa. Disebutkan dalam Undangundang Nomor 6 Tahun 2014, bahwa desa dan desa adat atau yang disebut dengan nama lain, selanjutnya disebut Desa, adalah kesatuan masyarakat hukum yang memiliki batas wilayah yang berwenang untuk mengatur dan mengurus urusan pemerintahan, kepentingan masyarakat setempat berdasarkan prakarsa masyarakat, hak asal usul, dan/atau hak tradisional yang diakui dan dihormati dalam sistem pemerintahan Negara Kesatuan Republik Indonesia.

Pemerintahan desa sebagai bagian dari sistem sosial memiliki peran yang sangat penting dalam pengelolaan modal sosial yang dimiliki oleh masyarakat (Sururi, 2017). Modal sosial masyarakat berupa nilai-nilai tradisional, kearifan lokal, sosial dan budaya dan kehidupan gotong royong merupakan kohesi masyarakat dalam menghadapi permasalahan ditengah perubahan dan dinamika global. Meskipun demikian kekuatan modal sosial tersebut perlu didukung dengan penyelenggaraan administrasi pemerintahan desa dan laporan keuangan desa yang tertib dalam rangka pelaksanaan pembangunan, pembinaan kemasyarakatan dan pemberdayaan masyarakat.

Dan dalam melaksanakan penyelenggaraan administrasi pemerintahan desa dan laporan keuangan desa yang tertib tersebut diperlukan aparatur pemerintahan desa dan masyarakat yang mampu dan memiliki kapasitas. Berdasarkan hasil analisis situasi sosial ditemukan permasalahan masih rendahnya kemampuan sumber daya manusia aparatur pemerintahan desa dalam pengelolaan penyusunan kebijakan desa dan manajemen pelayanan desa dan minimnya kemampuan tenaga 
pengelola keuangan desa sehingga menghambat penyusunan perencanaan keuangan desa. Dalam hal ini keberadaaan pendamping desa sebagai tenaga fasilitator desa masih belum dapat memberikan daya dukung terhadap peningkatan kapasitas aparatur pemerintahan desa dan masyarakat.

Dalam konteks penyelenggaraan pemerintahan daerah yang terpenting adalah bagaimana pemerintahan desa mampu meningkatkan kesejahteraan rakyatnya, mampu memberikan pelayanan kepada masyarakat desa, dan mampu meningkatkan daya saing desanya. (LAN-RI, 2009). Oleh sebab itu peningkatan kapasitas aparatur desa dalam tata kelola administrasi pemerintahan desa menjadi hal yang sangat penting. Dalam hal ini upaya bagi aparatur pemerintahan desa untuk mengikuti pelatihan administrasi pemerintahan desa perlu dilakukan.

Tugas dan tanggung jawab pemerintahan desa adalah menyelenggarakan Musrenbang sebagai forum musyawarah perencanaan pembangunan desa dan menyusun Rencana Pembangunan Jangka Menengah Desa (RPJMDesa) dan Rencana Kerja
Pemerintahan Desa (RKPDes), akan tetapi pada pelaksanaannya Musrenbang belum dilakukan berdasarkan prinsip-prinsip perencanaan dan kebutuhan dasar masyarakat desa dan hanya terfokus pada pembangunan infrastruktur jalan. Dalam hal ini masyarakat belum diberikan ruang untuk menyuarakan aspirasinya karena berbagai alasan seperti kepercayaan yang terlalu besar terhadap kepala desa dan besarnya pengaruh dan dominasi aparatur desa. Meskipun musyawarah perencanaan pembangunan desa sudah dilaksanakan akan tetapi masih terdapat berbagai permasalahan terkait dengan aspek pengambilan keputusan perencanaan pembangunan desa yang masih bersifat sentralistik dimana masih besarnya pengaruh kepala desa dan aparat desa dalam pengambilan keputusan (Sururi, 2017).

Dengan melihat berbagai permasalahan desa baik dari aspek administrasi pemerintahan maupun tata kelola keuangan desa terutama dalam meningkatkan kapasitas aparatur pemerintahan desa dalam mewujudkan tertib administrasi desa yang mampu berfungsi sebagai sumber data dan 
informasi

$$
\text { dalam }
$$$$
\text { penyelenggaraan }
$$

pemerintahan

Desa,

pelaksanaan

pembangunan, pembinaan kemasyarakatan

dan pemberdayaan masyarakat, maka solusi

yang ditawarkan adalah mengadakan kegiatan

pengabdian masyarakat melalui pelatihan

administrasi pemerintahan desa dan tata

kelola keuangan desa yang dilakukan oleh tim

pengabdian masyarakat bekerjasama dengan

aparatur Desa dan masyarakat Desa

Sukamenak Kecamatan Cikeusal Kabupaten

Serang.

Rumusan masalah yang menjadi fokus

kegiatan pengabdian masyarakat ini adalah bagaimana sosialisasi dan pelatihan administrasi pemerintahan maupun tata kelola laporan keuangan desa terutama dalam meningkatkan kapasitas aparatur pemerintahan desa dalam mewujudkan tertib administrasi desa. Adapun tujuan dari kegiatan pengabdian ini adalah : a).Memberdayakan dan meningkatkan keterampilan aparatur dan masyarakat desa tentang administrasi pemerintahan desa; b).Meningkatkan pengetahuan aparatur dan masyarakat desa dengan fokus pada laporan keuangan desa;

c).Mendorong

tertib

administrasi pelayanan desa.

\section{B. Metode Pelaksanaan Kegiatan}

Metode yang digunakan adalah

Participatory Learning And Action

merupakan bentuk baru dari metode pemberdayaan masyarakat yang sebelumnya lebih dikenal dengan „Learning by Doing" atau belajar sambil bekerja (Phuyal, 2008; IIED, 2013 dalam Mardikanto,2013), Participatory Learning Action merupakan proses belajar secara berkelompok yang dilakukan secara interaktif dalam suatu proses kerja (Appel dkk, 2012). Kegiatan berkonsep Participatory Learning and Action ini dilakukan dengan menekankan pada kegiatan ceramah, diskusi, curah pendapat yang dilakukan secara interaktif dengan anggota kelompok dan dilanjutkan dengan aksi atau kegiatan riil yang relevan dengan materi pemberdayaan masyarakat. (Theresia, 2014)

Kegiatan ini diikuti oleh aparatur pemerintahan Desa Sukamenak yang berjumlah 9 (sembilan) orang dan perwakilan 
masyarakat yang berjumlah 10 (sepuluh) orang. Pelaksanaan kegiatan pengabdian ini akan dilaksanakan melalui tiga tahap yaitu tahap awal, tahap inti dan tahap akhir. Secara umum tahapan kegiatan pengabdian ini dapat dilihat pada gambar 1 .

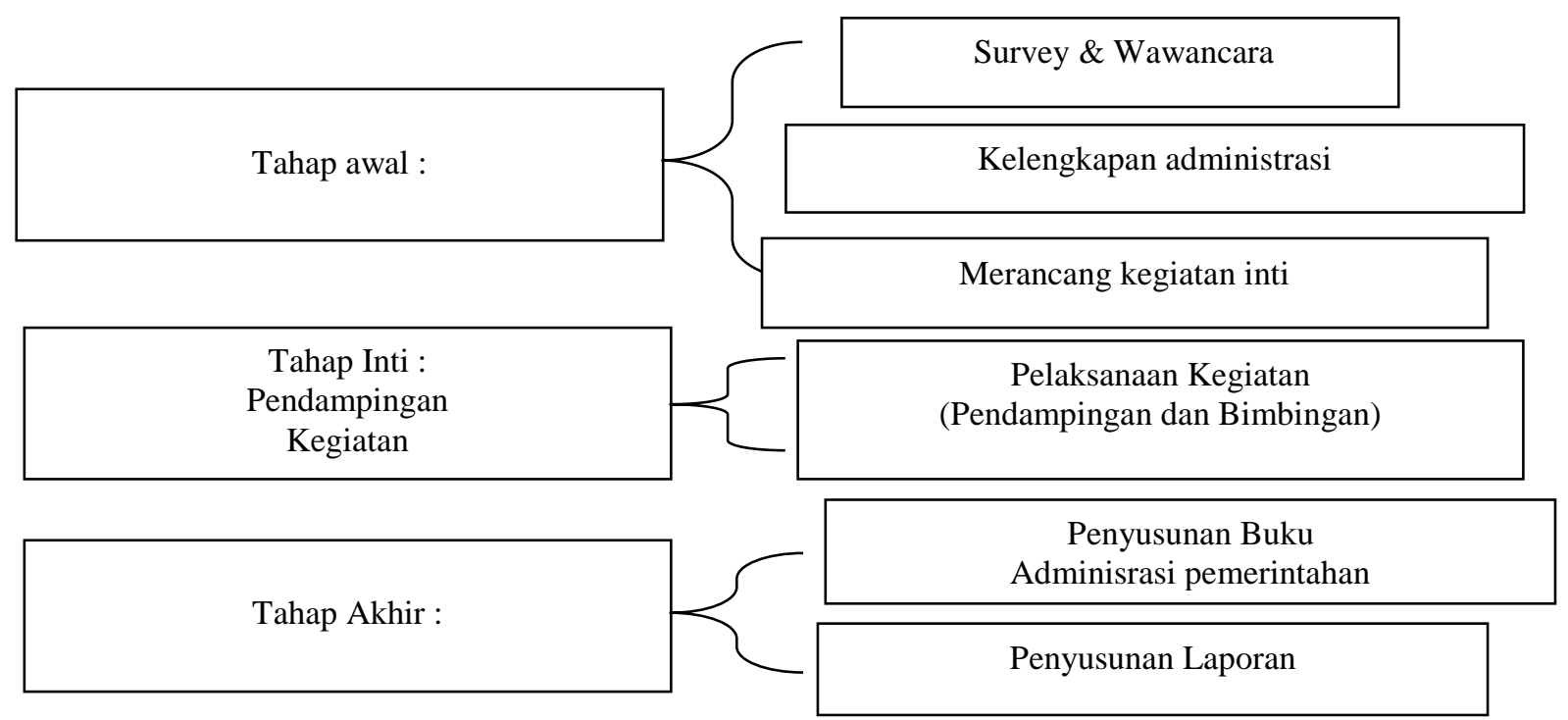

Gambar 1

Bagan Tahapan Kegiatan Pengabdian Masayarakat

Dan Berikut penjelasan pada masing-masing tahap kegiatan.

1. Tahap awal. Kegiatan pada tahap ini meliputi (a).Survey. Dilakukan sebagai analisis awal untuk mendapat informasi mendalam dan menyeluruh mengenai permasalahan mitra dan mencari solusi yang dibutuhkan dan tepat sasaran; (b).Kelengkapan administrasi dilakukan sebagai prosedur formal untuk melegalkan kegiatan pengabdian; dan (c).Merancang kegiatan inti dan menyusun modul pelatihan yang sesuai dengan kebutuhan mitra dan sebagai solusi dari permasalahan yang dihadapi.

2. Tahap inti. Dalam tahap kedua ini, fokus kegiatan pengabdian dilakukan yaitu pendampingan dan bimbingan kepada mitra melalui serangkaian pelatihan. Kegiatan pelatihan yang akan diikuti oleh mitra, yaitu sosialisasi knowledge sharing penataan tata kelola administrasi pemerintahan desa dan manajemen kelembagaan seperti penataan buku administrasi pelayanan masyarakat dan buku 
administrasi keuangan. Target sasaran peserta pelatihan adalah aparatur pemerintahan desa dan masyarakat. Selanjutnya dilakukan kegiatan evaluasi dengan melihat indikator tahapan perubahan perilaku berdasarkan skala 025 kategori rendah, skala 26-50 kategori kurang, skala 51-75 kategori cukup dan skala 76-100 kategori tinggi.

3. Tahap akhir. Ada tiga kegiatan dalam tahap ini yaitu (a).Evaluasi kegiatan yang akan dilakukan per kegiatan dan secara menyeluruh; (b).Penyusunan modul pelayanan desa.

\section{Hasil dan Pembahasan}

Kegiatan pendampingan ini dilakukan selama 1 (satu) bulan yaitu minggu pertama s/d minggu keempat bulan Agustus 2017

\section{Tahap Awal (Survey dan Analisis}

\section{Situasi Sosial)}

Pada tahap ini kegiatan survey dan analisis situasi dilakukan dengan melibatkan beberapa warga desa dengan tujuan untuk melakukan identifikasi potensi dan permasalahan yaitu aspek kelembagaan desa, aspek manajemen pelayanan aparatur desa, aspek transparansi penggunaan dan pelaporan keuangan desa, aspek pembangunan desa, aspek kesehatan, aspek infrastruktur (fasilitas umum dan fasilitas sosial desa) dan aspek kebijakan pemerintahan desa.

Kegiatan difokuskan terhadap sejumlah wilayah dan melakukan wawancara terhadap jumlah kepala keluarga. Hasil survey selanjutnya diolah dengan membuat matrik hasil survey dan wawancara

Tabel 1

Hasil Survey dan Analisis Situasi Sosial

\begin{tabular}{|c|l|l|}
\hline No & \multicolumn{1}{|c|}{ Aspek } & \multicolumn{1}{c|}{ Hasil Survey dan Wawancara } \\
\hline 1 & Kelembagaan Desa & $\begin{array}{l}\text { Desain kelembagaan masih menggunakan pola } \\
\text { tradisional }\end{array}$ \\
\hline 2 & $\begin{array}{l}\text { Manajemen pelayanan } \\
\text { aparatur desa }\end{array}$ & $\begin{array}{l}\text { Masih belum memberikan kepuasan terhadap } \\
\text { masyarakat dari sisi kemudahan dan kecepatan } \\
\text { pelayanan yang diberikan }\end{array}$ \\
\hline 3 & $\begin{array}{l}\text { Transparansi penggunaan } \\
\text { dan pelaporan keuangan } \\
\text { desa }\end{array}$ & $\begin{array}{l}\text { Dalam beberapa forum musyawarah desa, } \\
\text { sosialisasi penggunaan dan pelaporan keuangan } \\
\text { desa sudah dilakukan akan tetapi belum dilakukan } \\
\text { secara terbuka dan tidak dapat diakses oleh } \\
\text { masyarakat secara luas. }\end{array}$ \\
\hline
\end{tabular}




\begin{tabular}{|c|l|l|r|}
\hline 4 & Pembangunan desa & $\begin{array}{l}\text { Pelaksanaan } \\
\text { perencanaan pembangunan desa sudah } \\
\text { dilaksanakan meskipun belum dilaksanakan } \\
\text { berdasarkan prinsip-prinsip perencanaan dan } \\
\text { pembangunan desa belum melihat aspek } \\
\text { kebutuhan dasar masyarakat }\end{array}$ \\
\hline 5 & Kesehatan & $\begin{array}{l}\text { Perilaku hidup masyarakat untuk hidup sehat } \\
\text { sangat tinggi meskipun terdapat keterbatasan }\end{array}$ \\
\hline 6 & Infrastruktur & $\begin{array}{l}\text { Pembangunan infrastruktur oleh pemerintahan } \\
\text { desa sudah dilakukan sampai dengan saat ini } \\
\text { meskipun masih belum menyentuh aspek } \\
\text { kebutuhan pelayanan dasar masyarakat }\end{array}$ \\
\hline 7 & Kebijakan & $\begin{array}{l}\text { Pengambilan keputusan masih bersifat sentralistik } \\
\text { dan kebijakan dilakukan secara top down }\end{array}$ \\
\hline
\end{tabular}

Sumber : Diolah dari hasil survey, 2017

2. Tahap Inti (Kegiatan Pendampingan)

Pada tahap ini, kegiatan yang dilakukan adalah :

\section{a) Sosialisasi program;}

Sosialisasi pada masyarakat diberikan terkait dengan program yang akan dilaksanakan. Kegiatan dilaksankan di Kantor desa dengan dihadiri oleh masyarakat. Pada tahap ini, tim pengabdian masyarakat bersama-sama mahasiswa melakukan sosialisasi program pelatihan administrasi Pemerintahan Desa dan pelatihan tata kelola Laporan keuangan desa yang akan dilaksanakan di Desa Sukamenak selama satu minggu sekali selama satu bulan.

\section{Tabel 2}

Jadwal Pelatihan Administrasi Pemerintahan Desa dan Tata Kelola Laporan Keuangan Desa

\begin{tabular}{|c|l|c|c|}
\hline No & \multicolumn{1}{|c|}{ Kegiatan } & Waktu & Ket. \\
\hline 1 & Sosialisasi Program & 05 Agustus 2017 & Tim \\
\hline 2 & $\begin{array}{l}\text { Pendampingan } \\
\text { Pelatihan Administrasi }\end{array}$ & 12-13 Agustus & Budi Hasanah, M.Si \\
\hline 3 & $\begin{array}{l}\text { Pemerintahan Desa } \\
\text { pendampingan }\end{array}$ & 19-2017 Agustus & Ahmad Sururi, M.Si \\
& Keuangan Desa & 2017 & Tim \\
\hline 4 & $\begin{array}{l}\text { Pendampingan } \\
\text { Penyusunan buku } \\
\text { Administrasi }\end{array}$ & 26-27 Agustus & \\
& $\begin{array}{l}\text { Pemerintahan Desa dan } \\
\text { laporan keuangan }\end{array}$ & & \\
\hline
\end{tabular}


Kegiatan sosialisasi program yang diadakan pada tanggal 05 Agustus 2017 ini dihadiri oleh kepala desa, ketua BPD dan masyarakat bertempat di Kantor Kepala Desa Sukamenak. Respon yang diberikan masyarakat terhadap kegiatan ini sangatlah antusias dan mendorong agar kegiatan pelatihan dapat dilaksanakan secara

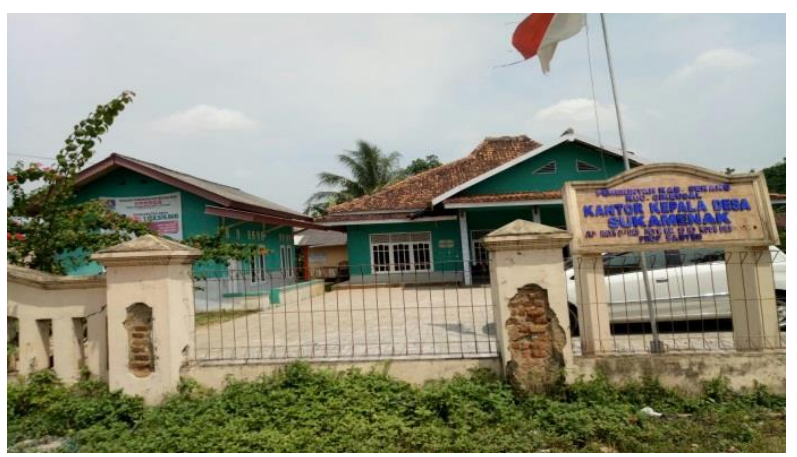

berkelanjutan. Selanjutnya kepala desa dalam sambutannya mengharapkan agar kegiatan pengabdian ini dapat meningkatkan pemahaman dan keterampilan aparatur pemerintahan desa serta menjadi motivasi dalam memberikan pelayanan optimal kepada masyarakat.

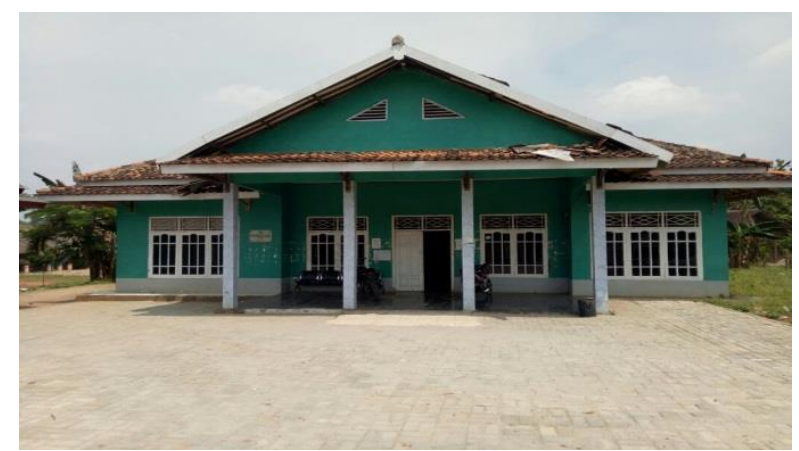

\section{Gambar 2}

\section{Kantor Desa Sukamenak Kecamatan Cikeusal}

\section{b) Pendampingan pelatihan Administrasi}

\section{Pemerintahan desa;}

Kegiatan pendampingan diikuti oleh aparatur pemerintahan desa dan masyarakat. Materi-materi yang diberikan dalam kegiatan pendampingan ini adalah tentang buku peraturan desa, buku keputusan kepala desa, buku inventaris dan kekayaan desa, buku aparatur pemerintahan desa, buku tanah kas desa, buku agenda, buku agenda, buku lembaran desa dan berita desa.
Kegiatan yang dilaksanakan pada tanggal 12 s/d 13 Agustus 2017 ini diikuti oleh seluruh aparatur pemerintahan desa yang berjumlah 9 (sembilan) orang dan 10 (sepuluh) orang dari perwakilan masyarakat. Kegiatan yang dilaksanakan selama 2 (dua) hari tersebut diberikan pengenalan teori dan praktek penyusunan buku-buku administrasi pemerintahan desa. Dan untuk mengetahui bagaimana tingkat keberhasilan pencapaian kegiatan pendampingan dilakukan evaluasi 
melalui indikator tahapan perubahan perilaku dapat dilihat pada tabel 3 sebagai berikut : pengetahuan, sikap dan keterampilan yang

Tabel 3

Indikator Tahapan Perubahan Perilaku dan persentase pemahaman materi administrasi Pemerintahan Desa

\begin{tabular}{|c|c|c|}
\hline Tujuan & Indikator & Persentase Pemahaman \\
\hline \multirow{4}{*}{ Pengetahuan } & $\begin{array}{l}\text { Aparatur pemerintahan desa dan } \\
\text { masyarakat mengetahui dan } \\
\text { memahami penyusunan buku } \\
\text { peraturan desa dan buku aparatur } \\
\text { pemerintahan desa }\end{array}$ & 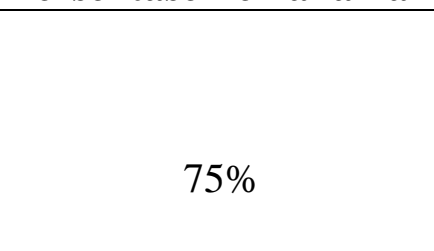 \\
\hline & $\begin{array}{l}\text { Aparatur pemerintahan desa dan } \\
\text { masyarakat mampu memahami } \\
\text { buku keputusan kepala desa dan } \\
\text { buku agenda, }\end{array}$ & $75 \%$ \\
\hline & $\begin{array}{l}\text { Aparatur pemerintahan desa dan } \\
\text { masyarakat mengetahui jenis- } \\
\text { jenis buku inventaris, buku tanah } \\
\text { kas desa dan kekayaan desa }\end{array}$ & $70 \%$ \\
\hline & $\begin{array}{l}\text { Aparatur pemerintahan desa dan } \\
\text { masyarakat mampu mengetahui } \\
\text { dan memahami buku lembaran } \\
\text { desa dan berita desa }\end{array}$ & $75 \%$ \\
\hline Sikap & $\begin{array}{lr}\text { Aparatur pemerintahan desa dan } \\
\text { masyarakat } & \text { menerima/ } \\
\text { memperhatikan, } & \text { menilai, } \\
\text { mengorganisir, } & \text { menanggapi } \\
\text { pentingnya } & \text { administrasi } \\
\text { pemerintahan desa } & \\
\end{array}$ & $65 \%$ \\
\hline Keterampilan & $\begin{array}{l}\text { Aparatur pemerintahan desa dan } \\
\text { masyarakat trampil dalam } \\
\text { penyusunan buku administrasi } \\
\text { pemerintahan desa }\end{array}$ & $70 \%$ \\
\hline & Rata-rata & $71 \%$ \\
\hline
\end{tabular}

Pada tabel 3 digambarkan bahwa ratarata perubahan perilaku aparatur dan masyarakat desa sebesar $71 \%$ atau berada pada kategori cukup, hal ini disebabkan kesadaran dan kemauan masyarakat untuk mengikuti kegiatan pelatihan sangat besar, dengan demikian dapat diindikasikan bahwa tingkat perubahan perilaku aparatur pemerintahan desa dan masyarakat setelah mengikuti kegiatan pelatihan cukup baik, sedangkan sisanya sebesar $29 \%$ perlu dilakukan evaluasi lebih lanjut. 

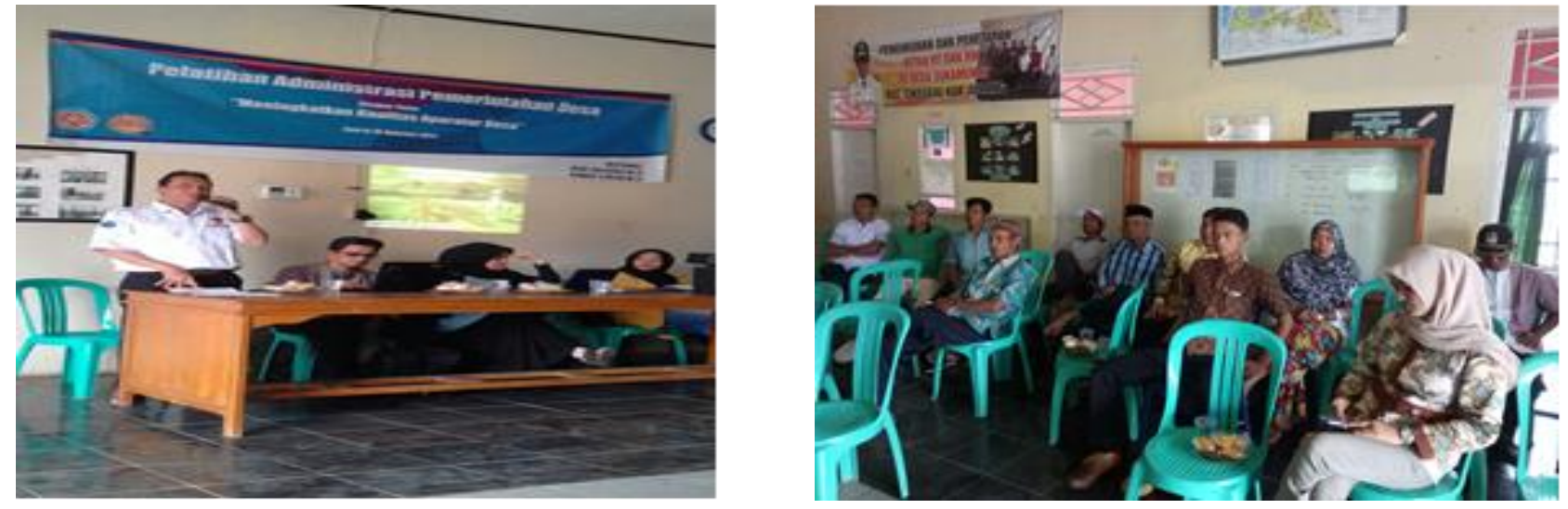

\section{Gambar 3}

\section{Kegiatan Pelatihan Administrasi Pemerintahan Desa}

\section{c) Pendampingan pelatihan Tata Kelola}

\section{Keuangan Desa.}

Pada kegiatan pendampingan ini, masyarakat difokuskan untuk dapat mempraktekkan dan menyusun laporan pertanggungjawaban Anggaran Pendapatan dan Belanja (APBDes). Output yang diharapkan adalah masyarakat terutama aparatur pemerintahan desa mampu menyusun dan menyampaikan laporan atas pelaksanaan tugas, kewenangan, hak, dan kewajibannya dalam pengelolaan keuangan desa. Laporan tersebut bersifat periodic yaitu semesteran dan tahunan, yang disampaikan ke Bupati/Walikota dan ke Badan Permusyawaratan Desa (BPD). Laporan dimaksud terdiri dari: 1).Laporan realisasi pelaksanaan APBDesa; 2).Laporan pertanggungjawaban Realisasi pelaksanaan APBdesa kepada bupati/walikota setiap akhir tahun anggaran; 3).Laporan Realisasi Penggunaan Dana Desa. Kegiatan dilaksanakan pada tanggal 19-20 Agustus 2017 dan diikuti oleh 7 (tujuh) orang aparatur pemerintahan desa dan 10 (sepuluh) perwakilan masyarakat.

Dan untuk mengetahui bagaimana tingkat keberhasilan pencapaian kegiatan pendampingan pelatihan laporan keuangan desa dilakukan evaluasi melalui indikator tahapan perubahan perilaku pengetahuan, sikap dan keterampilan yang dapat dilihat pada tabel 4 sebagai berikut : 
Tabel 4

Indikator Tahapan Perubahan Perilaku dan persentase pemahaman materi Laporan Keuangan Desa

\begin{tabular}{|c|c|c|}
\hline Tujuan & Indikator & Persentase Pemahaman \\
\hline \multirow[t]{2}{*}{ Pengetahuan } & $\begin{array}{l}\text { Aparatur pemerintahan } \\
\text { desa dan masyarakat } \\
\text { mengetahui r dan } \\
\text { memahami penyusunan } \\
\text { laporan realisasi } \\
\text { pelaksanaan APBDesa }\end{array}$ & $65 \%$ \\
\hline & $\begin{array}{l}\text { Aparatur pemerintahan } \\
\text { desa dan masyarakat } \\
\text { mampu menyusun } \\
\text { laporan } \\
\text { pertanggungjawaban } \\
\text { Realisasi pelaksanaan } \\
\text { APBdesa kepada } \\
\text { bupati/ walikota setiap } \\
\text { akhir tahun anggaran, }\end{array}$ & $60 \%$ \\
\hline Sikap & $\begin{array}{l}\text { Aparatur pemerintahan } \\
\text { desa dan masyarakat } \\
\text { menerima/ } \\
\text { memperhatikan, } \\
\text { menilai, mengorganisir, } \\
\text { menanggapi pentingnya } \\
\text { laporan keuangan desa }\end{array}$ & $65 \%$ \\
\hline Keterampilan & $\begin{array}{l}\text { Aparatur pemerintahan } \\
\text { desa dan masyarakat } \\
\text { mengetahui dan } \\
\text { memahami penyusunan } \\
\text { laporan realisasi \& } \\
\text { pertanggungjawaban } \\
\text { keuangan desa }\end{array}$ & $65 \%$ \\
\hline \multicolumn{2}{|c|}{ Rata-rata } & 63,75 \\
\hline
\end{tabular}

Pada tabel 4 digambarkan bahwa rata-

rata perubahan perilaku aparatur dan masyarakat desa sebesar $63,75 \%$ atau berada pada kategori cukup, hal ini disebabkan aparatur pemerintahan desa dan masyarakat menilai bahwa penyusunan laporan keuangan desa sangat penting untuk dipahami dan diketahui oleh seluruh masyarakat. Dengan demikian dapat diindikasikan bahwa tingkat perubahan perilaku aparatur pemerintahan desa dan masyarakat setelah mengikuti kegiatan pelatihan cukup baik, sedangkan sisanya sebesar $36,25 \%$ perlu dilakukan evaluasi lebih lanjut. 

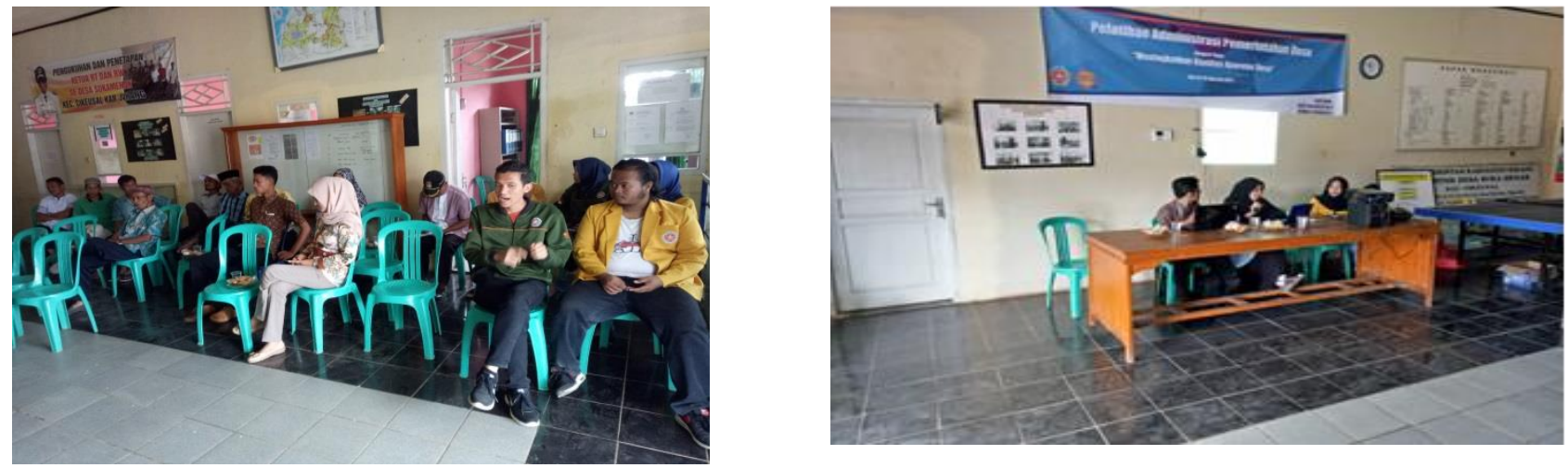

\section{Gambar 4}

Pelatihan Tata Kelola Pelaporan Keuangan Desa

\section{Tahap akhir (Kegiatan pendampingan)}

Ada dua kegiatan dalam tahap ini yaitu pendampingan penyusunan buku administrasi pemerintahan desa dan laporan keuangan desa. Pada tahap ini, aparatur pemerintahan desa dan masyarakat bersama-sama menyusun dan mempraktekan hasil pelatihan bersama-sama tim pengabdian masyarakat. Kegiatan yang dilaksanakan selama 2 (dua) hari tersebut yaitu pada tanggal 26-27 Agustus 2017 sekaligus sebagai tahap evaluasi untuk memantau dan menilai sejauhmana masyarakat dapat mempraktekkan hasil pelatihan yang telah diberikan.

\section{Kesimpulan dan Rekomendasi}

\section{1) Kesimpulan}

Dari kegiatan yang telah dilaksanakan, dapat disimpulkan beberapa hal sebagai berikut :

a) Tingkat keberhasilan pencapaian dengan menggunakan indikator perubahan perilaku untuk kegiatan pelatihan administrasi pemerintahan desa dan laporan keuangan adalah sebesar $71 \%$ dan 63,75\% yaitu berada pada kategori cukup.

b) Aparatur Pemerintahan Desa dan masyarakat Desa Sukamenak Kecamatan Cikeusal sebagai mitra pengabdian masyarakat memiliki respon dan antusias yang sangat besar terutama dalam proses pelatihan walaupun dengan segala keterbatasan yang dimiliki.

c) Kegiatan pengabdian masyarakat masyarakat antara tim pengabdian 
bersama-sama masyarakat di Desa

Sukamenak Kecamatan Cikeusal melalui

kegiatan pelatihan administrasi

pemerintahan desa dan laporan keuangan

berjalan sesuai dengan rencana dan target

yang telah ditetapkan.

\section{2) Rekomendasi}

Adapun rekomendasi dalam kegiatan ini adalah :

1. Penyusunan laporan administrasi pemerintahan desa dan pelaporan keuangan desa yang telah dilakukan secara mandiri dapat disosialisasikan kepada seluruh masyarakat.

2. Mendorong diadakannya kegiatan pelatihan administrasi Pemerintahan Desa dan pelaporan keuangan desa dilaksanakan secara rutin dan berkelanjutan.

\section{Daftar Pustaka}

Lembaga Administrasi Negara, 2009. Peningkatan Kapasitas Aparatur Desa, Pusat Kajian Kinerja Otonomi Daerah, Jakarta.

Mardikanto T dan Soebiato P, 2013, Pemberdayaan Masyarakat dalam Perspektif Kebijakan Publik. Alfabeta, Bandung.

Sururi, Ahmad dan Mulyasih Rahmi, 2017. Engagement, Jurnal Pengabdian Masyarakat Kopertais IV Surabaya, Volume 1 Nomor 2.

Sururi, Ahmad dan Muyasih Rahmi, 2017. Wikrama Prahita, Jurnal Pengabdian Masyarakat Universitas Serang Raya, Volume 1 Nomor 1.

Theresia, Aprillia, at al, 2014, Pembangunan Berbasis Masyarakat. Bandung, Alfabeta

Undang-undang Nomor 6 Tahun 2014 tentang Desa 